\title{
Otolith geochemistry indicates life-long spatial population structuring in a deep-sea fish, Coryphaenoides rupestris
}

\author{
C. Longmore ${ }^{1}$, C. N. Trueman ${ }^{2}$, F. Neat ${ }^{3}$, E. J. O'Gorman ${ }^{1}$, J. A. Milton ${ }^{2}$, S. Mariani ${ }^{1,4, *}$ \\ ${ }^{1}$ MarBEE, UCD School of Biology \& Environmental Science, University College Dublin, Belfield, Dublin 4, Ireland \\ ${ }^{2}$ School of Ocean and Earth Science, National Oceanography Centre, University of Southampton Waterfront Campus, \\ Southampton SO14 3ZH, UK \\ ${ }^{3}$ Marine Scotland-Science, The Marine Laboratory, Aberdeen AB11 9DB, UK
}

${ }^{4}$ Present address: School of Environment \& Life Sciences, The University of Salford, M5 4WT, UK

\begin{abstract}
Little is understood about connectivity of deep-sea fish populations. Analysis of the geochemical properties of fish otoliths is one way to draw inferences regarding their movements and habitat use in the marine environment. Trace element and stable isotope analyses of otoliths were undertaken to assess patterns of spatial and temporal population structure of a wide-ranging deepwater fish, the roundnose grenadier Coryphaenoides rupestris. Fish were sampled from 4 locations across the distribution range of the species in the northeast Atlantic. Multivariate analyses of elemental ratios $(\mathrm{Li} / \mathrm{Ca}, \mathrm{Mn} / \mathrm{Ca}, \mathrm{Ba} / \mathrm{Ca}, \mathrm{Zn} / \mathrm{Ca}, \mathrm{Cu} / \mathrm{Ca}$ ) revealed strong geographic separation at each life stage, and an overall significant difference between life stages. Otolith oxygen $\left(\delta^{18} \mathrm{O}\right)$ and carbon $\left(\delta^{13} \mathrm{C}\right)$ stable isotope analysis indicated a depth migration (and reduction in metabolic activity) from relatively shallow in the juvenile phase to much deeper in the adult phase at all locations. The results suggest that roundnose grenadier are comprised of geographically distinct population units that persist throughout their life-history, migrating deeper as they get older.
\end{abstract}

KEY WORDS: Roundnose grenadier - North Atlantic · Otolith microchemistry · Stable isotopes · Population connectivity $\cdot$ Laser ablation ICP-MS

\section{INTRODUCTION}

Marine fish stocks have long been assumed to be homogeneous, self perpetuating demographic units, with a high degree of connectivity over long distances (Ihssen et al. 1981, Carvalho \& Hauser 1994). Hilborn \& Walters (1992) define a fish stock as any discrete, selfsustaining group of fish, usually subject to a particular fishery, which sometimes exhibit particular life-history characteristics that may or may not have a genetic basis. Often there is significant spatial structuring or clustering between and within stocks and, since stock components may vary in size and resilience to exploitation, spatial structuring must be understood if the stocks are to be sustainably managed as a natural resource (Hauser \& Carvalho 2008).

The techniques used to identify stocks and stock structure are many and diverse (Cadrin et al. 2005, Waples et al. 2008). Genetic approaches have succeeded in identifying differences between stocks arising from adaptive divergence or genetic drift and limited gene flow (Carvalho \& Hauser 1994, Hauser \& Seeb 2008, Waples et al. 2008); however, genetic methods alone have little power to resolve contemporary demographic and life-history patterns within stocks and over ecological time scales (Lowe \& Allendorf 2010). Stock structure can also be assessed through environmentally-induced variation in the physiological 
and chemical make-up of individual fish, such as trace element concentrations in the otoliths (Campana 2005).

The otoliths of fish are acellular, metabolically inert calcified cephalic structures that function in hearing, balance and orientation. They are composed of calcium carbonate (mainly aragonite, with vaterite occasionally forming in damaged areas) and an organic protein matrix that is formed with daily and annual periodicity as the fish grows, resulting in increments and annuli. As the otolith forms, it incorporates a suite of minor and trace elements, which become a permanent record of the chemical characteristics of the environment that the fish was experiencing at the time (Elsdon \& Gillanders 2003, Stransky 2003). Therefore, populations of fish that occupy physicochemically distinct environments may be distinguished using otolith trace element analysis (Elsdon \& Gillanders 2004, Ashford et al. 2006, Elsdon et al. 2008, Kingsford et al. 2009, Wang et al. 2009).

The isotopic composition of oxygen and carbon in otolith aragonite (expressed as $\delta^{18} \mathrm{O}$ and $\delta^{13} \mathrm{C}$ values respectively) can also provide information relating to the ambient water temperature (and thus depth) (e.g. Høie et al. 2004b) and the relative metabolic activity (Sherwood \& Rose 2003) of the individual (Kalish 1991a,b, Thorrold et al. 1997, Campana 1999, Høie et al. 2004a, Shephard et al. 2007, Shiao et al. 2009). As the otolith aragonite grows, oxygen isotopes are precipitated in equilibrium with the endolymph fluid, which is itself in isotopic equilibrium with ambient seawater (Kalish 1991a, Thorrold et al. 1997, Campana 1999, Høie et al. 2004a,b). Fractionation (the physical phenomenon which causes changes in the relative abundance of isotopes due to their differences in mass) causes the partitioning of oxygen and carbon isotopes between seawater oxygen and aragonite and between dissolved inorganic carbon (DIC) and aragonite, respectively. Fractionation is related to temperature; the oxygen isotopic composition of the otolith is controlled by the ambient water $\delta^{18} \mathrm{O}$ which reflects ambient water temperature (Kalish 1991a). Consequently, the isotopic composition of otolith carbonate incorporated throughout the life of the fish can be used to reveal the ambient water temperature and thus fish location (Patterson et al. 1993, Ashford et al. 2006, Rooker et al. 2008).

One challenging frontier in otolith microchemical studies is the deep sea: while the highly variable physical and chemical nature of coastal environments often results in distinct signals in otolith chemical composition, there remains uncertainty as to the resolution of this technique in an environment such as the deep ocean, which is more environmentally homogeneous and where physiological influences on otolith composition (Kalish 1991b, Brown \& Severin 2009) may obscure any geographic differences. Yet, there have been recent successes on this front. Ashford et al. (2005) used laser ablation to sample otolith edges of the deep water Patagonian toothfish Dissostichus eleginoides to successfully discriminate between capture sites, while Ashford et al. (2006) used the chemistry of otolith nuclei of the same species to discriminate among areas of origin and to determine population structuring in this species. In an additional study using laser ablation inductively coupled plasma mass spectrometry (LAICP-MS), Ashford et al. (2008) were able to reveal further fine scale population structuring in this species and link this structuring to the Antarctic circumpolar front. Such studies indicate that otolith chemistry may have potential for use in stock identification of deep sea fish. A preliminary study using otolith chemistry on the deep-sea roundnose grenadier Coryphaenoides rupestris Gunnerus, 1765 (Longmore et al. 2010) suggested that population structure may potentially be revealed using this technique. In the present study the aim was to explore the population structure and life history of this species over its distribution range and across ontogenetic stages, using both trace element and stable isotope analyses.

The roundnose grenadier Coryphaenoides rupestris belongs to the family Macrouridae, a very diverse and successful group of deep sea fish with a worldwide distribution. This grenadier is a benthopelagic fish that is widely distributed in the North Atlantic. It is found mainly at depths of 600 to $1800 \mathrm{~m}$ along the continental slopes from $37^{\circ} \mathrm{N}$ off the USA to about $66^{\circ} \mathrm{N}$ off Canada, in an area stretching along the slope of Baffin Island and West Greenland to Iceland and around mainland Europe (Cohen et al. 1990) including the Mid-Atlantic Ridge (MAR) (Bergstad et al. 2010). The reported temperature range for this species in the eastern North Atlantic is from 4 to $11.5^{\circ} \mathrm{C}$ (Ellett \& Martin 1973, Bridger 1978, Ehrich 1983, Rice et al. 1991). It grows to $>100 \mathrm{~cm}$ total length (TL) (Kelly et al. 1997), displaying a general trend of increasing size with depth (Atkinson 1995). Its diet is diverse but it feeds predominantly on amphipods and copepods as a juvenile, becoming increasingly piscivorous with size (Mauchline et al. 1994, Bergstad et al. 2010). Reproduction of the roundnose grenadier in the northeast Atlantic is prolonged, lasting from February to November and peaking in the warmer months of May to November (Allain 2000). In the area of the Skagerrak however (Fig. 1), spawning is thought to occur only in autumn (Bergstad \& Gordon 1994). Age at first maturity is approximately 9 to 11 yr (Bergstad 1990, Kelly et al. 1996) and it is not unusual for $C$. rupestris to reach ages of $>40$ yr (Kelly et al. 1996, 1997, Lorance et al. 2001).

While some evidence exists that the population of roundnose grenadier in the Skagerrak may be an inde- 
pendent unit (Bergstad 1990), the population structure throughout the rest of the North Atlantic remains unclear. Some studies have reported genetic heterogeneity across populations in the North Atlantic, indicating possible demographic independence (Logvinenko et al. 1983, Duschenko \& Savvatimskiy 1988, White et al. 2010). Here we use LAICP-MS and stable isotope analysis of otoliths to infer stock structuring in roundnose grenadier across the northeast Atlantic. Specifically, we test whether fish from the different areas are likely to form independent populations, or whether some degree of population connectivity exists at some stage of the life cycle. Additionally, we investigate the extent and the timing of switches to different depths during ontogeny.

\section{MATERIALS AND METHODS}

Sample collection. Roundnose grenadier Coryphaenoides rupestris were collected from 4 locations across the North Atlantic: the Skagerrak, Rockall Trough, Irish Slope and the MAR (Fig. 1, Table 1). All fish were caught by bottom trawling and therefore from approximately $5 \mathrm{~m}$ above the seabed. All fish from all locations ranged in size from 5 to $18 \mathrm{~cm}$ pre-anal fin length (PAFL), corresponding to an approximate TL of
Table 1. Coryphaenoides rupestris. Details of roundnose grenadier samples from 4 locations in the northeast Atlantic. PAFL: pre-anal fin length

\begin{tabular}{|lcccrc|}
\hline Location & N & Date & $\begin{array}{c}\text { Depth } \\
(\mathrm{m})\end{array}$ & $\begin{array}{c}\text { PAFL } \\
(\mathrm{cm})\end{array}$ & $\begin{array}{c}\text { Sex ratio } \\
(\mathrm{M} / \mathrm{F})\end{array}$ \\
\hline Rockall & 20 & Nov 07 & 950 & $8-18$ & $7 / 13$ \\
Skagerrak & 20 & Oct 01 & $231-498$ & $12-18$ & $4 / 16$ \\
$\begin{array}{l}\text { Mid-Atlantic } \\
\text { Ridge }\end{array}$ & 20 & Jul 04 & 985 & $5-17$ & $9 / 11$ \\
Irish Slope & 23 & Sep 06 & $1083-1550$ & $12-19$ & $7 / 16$ \\
\hline
\end{tabular}

between 20 to $85 \mathrm{~cm}$ (Atkinson 1981). PAFL (corresponding to a measurement from the tip of the snout to the base of the first anal fin ray) was preferred as a measure of length as the loss and subsequent regeneration of the end of the tail is common in this species due trawl damage or predation and so TL as a measurement may yield inconsistent results. Fish were measured to the nearest $0.5 \mathrm{~cm}$, weighed to the nearest $1 \mathrm{~g}$, and otoliths collected on board.

To determine the relationship between otolith isotopes and depth in deep water species, a further 49 otoliths from 17 species were sampled from a separate research cruise to the Irish Slope in 2006. Full details of

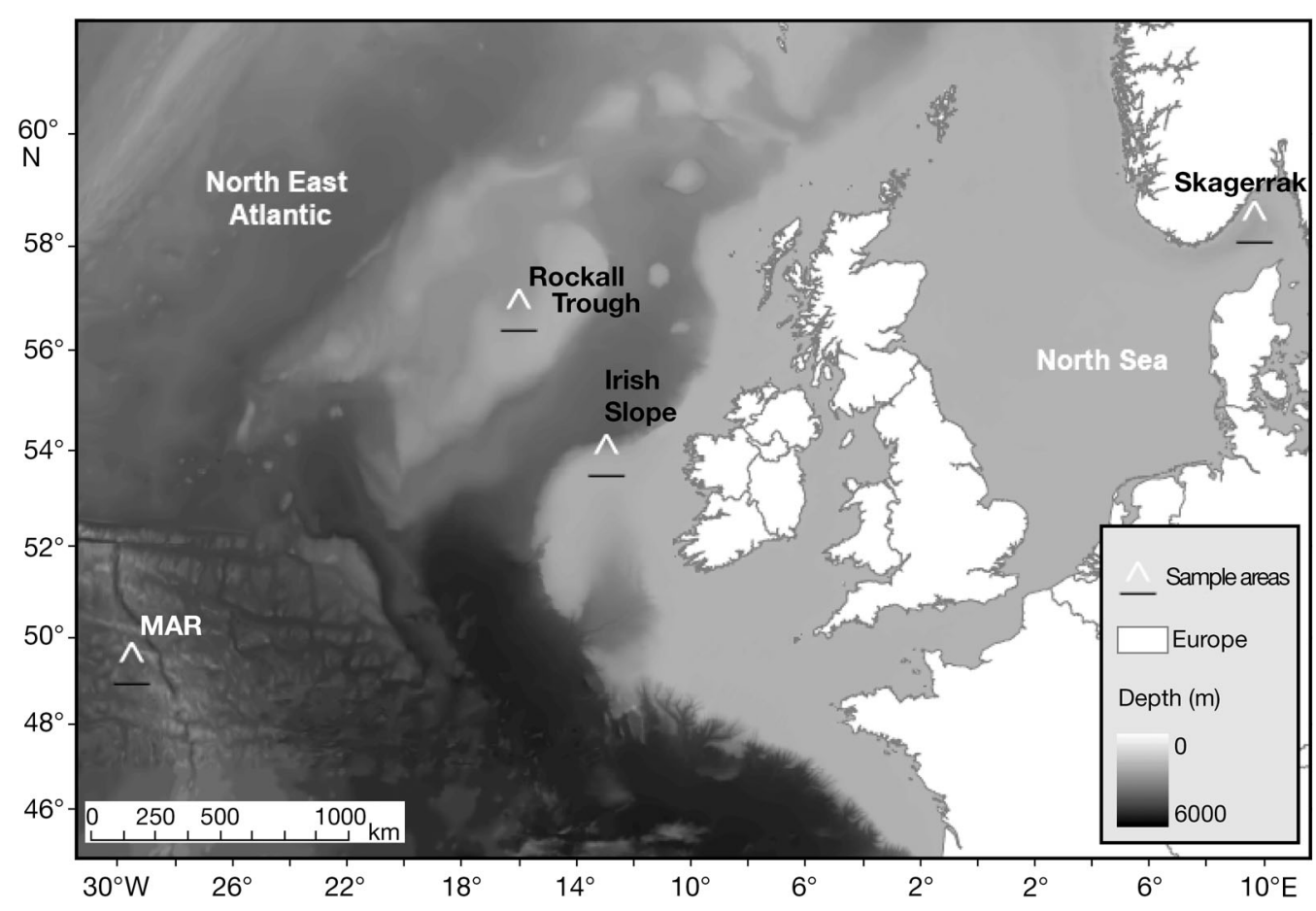

Fig. 1. Northeast Atlantic, showing the 4 study locations where roundnose grenadier Coryphaenoides rupestris were sampled. MAR: Mid-Atlantic Ridge 
Table 2. Coryphaenoides rupestris. Details of deep-sea fish otolith samples taken from the Irish Slope in 2006 and used to derive Eq. (2) for oxygen stable isotope analysis. $\delta^{18} \mathrm{O}_{\text {oto }}$ : measured otolith $\delta^{18} \mathrm{O}$ values; $\delta^{18} \mathrm{O}_{\mathrm{w}}$ : estimated isotopic composition of ambient water (see text for details)

\begin{tabular}{|lcrrrrr|}
\hline Species & $\begin{array}{c}\mathrm{N} \\
\text { Depth } \\
(\mathrm{m})\end{array}$ & $\delta^{18} \mathrm{O}_{\mathrm{oto}}$ & $\delta^{18} \mathrm{O}_{\mathrm{w}}$ & $\begin{array}{c}T \\
\left({ }^{\circ} \mathrm{C}\right)\end{array}$ & $\delta^{18} \mathrm{O}_{\mathrm{oto}}-\delta^{18} \mathrm{O}_{\mathrm{w}}$ \\
\hline Alepocephalus bairdii & 3 & 1300 & 2.68 & -29.69 & 5.86 & 32.3683 \\
Antimora rostrata & 2 & 1500 & 2.78 & -29.75 & 4.66 & 32.5295 \\
Beryx splendens & 2 & 500 & 1.51 & -29.55 & 9.51 & 31.0556 \\
Coryphaeonoides labiatus & 4 & 1500 & 2.65 & -29.75 & 4.66 & 32.4079 \\
Cataetyx laticeps & 3 & 1500 & 2.97 & -29.75 & 4.66 & 32.7257 \\
Coryphaenoides rupestris & 3 & 1300 & 2.89 & -29.69 & 5.86 & 32.5789 \\
Cottonculus thompsoni & 4 & 1200 & 2.85 & -29.67 & 6.58 & 32.5109 \\
Epigonis telescopus & 3 & 750 & 2.21 & -29.58 & 8.95 & 31.7838 \\
Helicolenus dactylopterus & 3 & 500 & 1.67 & -29.55 & 9.51 & 31.2203 \\
Lepidion eques & 4 & 750 & 2.03 & -29.58 & 8.95 & 31.6044 \\
Merluccius merluccius & 2 & 500 & 1.91 & -29.55 & 9.51 & 31.4532 \\
Mora moro & 3 & 1500 & 2.03 & -29.75 & 4.66 & 31.7821 \\
Micrometissus poutissou & 3 & 500 & 1.89 & -29.55 & 9.51 & 31.4412 \\
Nezumia aequalis & 3 & 750 & 2.19 & -29.58 & 8.95 & 31.7645 \\
Phycis blennoides & 2 & 750 & 2.07 & -29.58 & 8.95 & 31.6414 \\
Roulena attrita & 3 & 1500 & 2.99 & -29.75 & 4.66 & 32.7396 \\
Synaphobranchis kaupii & 2 & 1500 & 3.05 & -29.75 & 4.66 & 32.8067 \\
\hline
\end{tabular}

the species sampled are provided in Table 2. The otoliths (sagittae) were removed with plastic forceps to avoid metal contamination, and placed in paper envelopes. This method of storage has been shown to have the least impact on elemental concentrations (Milton \& Chenery 1998). Proctor \& Thresher (1998) showed that a delay in the removal of the otolith of just $3 \mathrm{~h}$ may influence the concentrations of a range of elements including sodium, potassium, calcium and strontium. In this study, otoliths were collected freshly from the dead specimens upon sorting of the catch and the abovementioned elements were not included in the analysis. Furthermore, Swan et al. (2006) found no effects of handling and storage on the elemental concentrations of Coryphaenoides rupestris otoliths using the same procedure as in this study.

Sample preparation. The same otolith was used for both trace element and stable isotope analysis. Around 20 individuals were selected at random from the total sample from each location. Otoliths were rinsed in Milli-Q water to remove any adhering sagittal membrane and further cleaned in an ultrasonic water bath to remove any remaining surface residue. Samples were then left to dry overnight in a laminar flow cabinet. Since it has been previously shown that there is little difference in elemental chemistry between left and right sagittal otoliths of the same fish (Rooker et al. 2001), only one randomly chosen otolith from each pair was used. Each otolith was then weighed using a Mettler Toledo microbalance to the nearest $0.001 \mathrm{~g}$. Otoliths were encased in Araldite epoxy resin blocks (Agar Scientific), and a $200 \mu \mathrm{m}$ transverse section was then taken either side of the core using a Buehler precision low-speed sectioning saw. Each section was polished using silicon carbide paper (P2400 $\rightarrow$ P4000) and finally polished using diamond paste on a lapping board. The surface for laser ablation analysis was rinsed with Milli-Q water and cleaned with absolute ethanol. The surface of each otolith was pre-ablated using the laser to remove any surface contaminants before the ICP-MS element detection. Over the course of both elemental analysis and isotope analysis, data from some otoliths was lost due to damage or machine related errors. Therefore, sample numbers differ slightly from the number collected and between analyses.

Otolith elemental analysis. Otolith sections were mounted in random order on a glass slide using crystal bond adhesive. The elemental data were acquired using a New Wave UP193FX laser ablation system coupled to a Thermo X-Series II ICP-MS (Electro Scientific Industries Europe) located at the University of Southampton, UK. The analysis parameters were as follows: spot size: $35 \mu \mathrm{m}_{\text {; }}$ pulse rate: $20 \mathrm{~Hz}$; energy: $60 \%$ (optimized); sweeps: 105; channels per mass: 1 ; channel width: 0.02 atomic mass units; acquisition time: $20 \mathrm{~s}$; dwell time: $10 \mathrm{~ms}_{\text {; }}$ 'wash' time between shots: $40 \mathrm{~s}$. To avoid depth-related fractionation effects, acquisition times were limited to $20 \mathrm{~s}$ to minimize depth penetration. The excimer laser parameters (e.g. energy, repetition rate) were optimized to limit fractionation. The following isotopes were acquired: ${ }^{7} \mathrm{Li},{ }^{24} \mathrm{Mg},{ }^{43} \mathrm{Ca},{ }^{44} \mathrm{Ca},{ }^{55} \mathrm{Mn},{ }^{59} \mathrm{Co},{ }^{60} \mathrm{Ni},{ }^{65} \mathrm{Cu}$, ${ }^{66} \mathrm{Zn},{ }^{88} \mathrm{Sr},{ }^{137} \mathrm{Ba},{ }^{238} \mathrm{U}$. As data were acquired using a standard ICP-MS instrument, all isotopes were measured at the same mass resolution. Standard reference materials SRM 612 and SRM 610 produced by the National Institute of Standards and Technology (NIST) were used for calibration. Each analysis session (typically 3 to 4 otoliths) was bracketed by NIST standard measurements to monitor reproducibility. All data were internally normalized to counts on ${ }^{44} \mathrm{Ca}$ to control for variable ablation efficiency between otolith regions with relatively high and low organic contents. ${ }^{43} \mathrm{Ca}$ counts were used as a post-normalization check.

Using a spot raster method, laser spots across the otolith following the annuli from primordium to the edge of the otolith were taken. Digital images of each otolith were taken after analysis, and individual laser pits were assigned to a life history stage based on otolith increment analysis. Laser pits were assigned to 
primordium (early larval), core (late larval), transition (juvenile) and edge (late adult) stages. For each life stage, the spots falling within that area identified in the otolith were averaged (Fig. 2a). The primordial zone and core boundary of the otolith was visible on the majority of otolith sections. In those otolith sections where the primordial zone was not visible (2 sections, due to sectioning error), an estimate of its location was made based on distance from the core boundaries. Typically the primordial zone was located approximately equidistant from the core zone boundaries, situated on the distal side of the core (which was always clearly visible) opposite the sulcus indent. This had little impact on results as elemental concentrations were generally highest in the primordial region. The transitional phase was taken as the first translucent zone surrounding the core (typically representing age 1; Gordon \& Swan 1996).
For the edge data, the last 10 spots at the edge of each otolith were deemed representative of the adult phase (covering approximately 3 to 5 annuli including both fast growth opaque and slow growth translucent rings). These spots were used to estimate average elemental concentrations representative of the sampling locations and the likely most recent environment inhabited by each fish. Although an age and growth analysis was not carried out for this study, it was found that fish size did not differ significantly among location $(F=0.91$, df $=3, \mathrm{p}<0.44)$, with a mean PAFL of 15.7 , 15.2, 14.8 and $15.7 \mathrm{~cm}$ for Rockall, Skagerrak, MAR and Irish Slope respectively. All fish sampled were mature adults and, as these fish are long lived and slow growing, the average elemental concentration represents many years in the adult phase. This would reduce (though not eliminate) any potential effect of differences in size (ages) among locations.
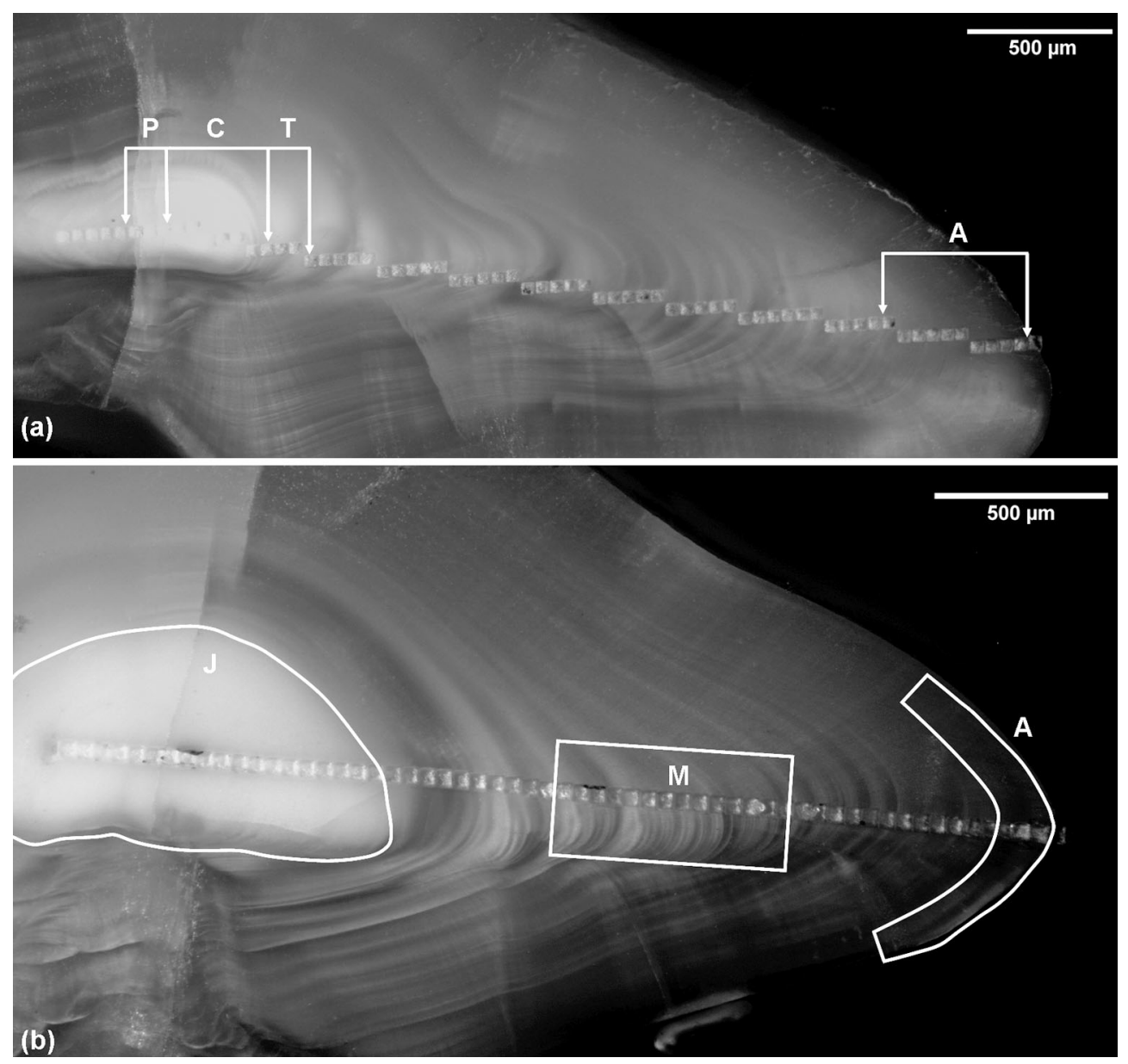

Fig. 2. Coryphaenoides rupestris. Roundnose grenadier otolith. (a) Otolith microchemistry analysis zones corresponding to the (P) primordial zone, representing the early larval phase; $(\mathrm{C})$ the core zone, representing the late larval phase; (T) the transitional zone; (A) the late adult phase, representative of most recent environment of the fish. (b) Isotope analysis zones, corresponding to the $(\mathrm{J})$ juvenile zone encompassing early larval/late larval phases; $(\mathrm{M})$ the mid-life stage; $(\mathrm{A})$ the late adult phase 
Stable isotope analysis. Sectioned otoliths used in laser ablation ICP-MS were also used for stable isotope analysis. Five otoliths were sub-sampled per location (Rockall, Skagerrak, MAR and Irish Slope). For each otolith, aragonite powder was sampled from the core, mid and edge of the otolith representing larval, midlife and late adult stages of life (Fig. 2b).

Otolith aragonite was sampled using a New Wave MicroMill (Electro Scientific Industries Europe). The temporal resolution for samples was defined by the minimum mass of aragonite powder that could be analyzed accurately for stable isotope composition. A target mass of $\sim 50 \mu \mathrm{g}$ powder was set and the volume of otolith milled estimated by assuming a conservative dry recovery rate of $\sim 70 \%$. As otoliths accrete faster in the direction of the principal growth axis, milling depths were chosen which were no deeper than the widths of the otolith growth zones to prevent drilling into unwanted material.

To compare measured isotope values with known temperatures in deep water fish, the outermost portion of the otoliths from the species outlined in Table 2 was sampled, maximizing the likelihood of capture location reflecting water conditions during otolith deposition. These otoliths were mounted whole onto glass slides, pressing the proximal surface into warm wax. The micromill was used to sample powder from the outer distal surface. Initially a surface profile was measured with the $z$-axis sensor, and a path calculated to sample at a depth no greater than $50 \mu \mathrm{m}$.

In all cases, stable isotope analyses were conducted by reacting $\sim 20$ to $150 \mu \mathrm{g}$ of aragonite powder with $100 \%$ phosphoric acid at $70^{\circ} \mathrm{C}$, evolving $\mathrm{CO}_{2}$, then purifying and analyzing on a Europa GEO instrument isotope ratio mass spectrometer. Accuracy and precision was continually monitored by repeat sampling of NBS-19 (reference material also known as TS-Limestone), otolith standard FEBS-1 (internal lab standard) and in-house Carrera marble standards. Analytical errors (standard error on repeat analyses of standards) are $<0.1 \%$ for both $\delta^{13} \mathrm{C}$ and $\delta^{18} \mathrm{O}$ values. Isotope data are reported in $\delta$ notation, relative to the Pee Dee Belemnite (PDB) carbonate standard.

To determine the relationship between measured otolith $\delta^{18} \mathrm{O}$ values $\left(\delta^{18} \mathrm{O}_{\text {oto }}\right)$ and temperature in deep water habitats, measurements of temperature and salinity at the location and depth of capture were extracted from the British Oceanographic Data Centre CTD dataset (www.bodc.ac.uk). Isotopic composition of ambient water $\left(\delta^{18} \mathrm{O}_{\mathrm{w}}\right)$ was estimated from the CTD data taking the relationship between $\delta^{18} \mathrm{O}_{\mathrm{w}}$ values and salinity in the North Atlantic (Craig \& Gordon 1965) to be

$$
\delta^{18} \mathrm{O}_{\mathrm{w}(\mathrm{PDB})}=(-21.2+0.61 S)^{*} 0.97002-29.9
$$

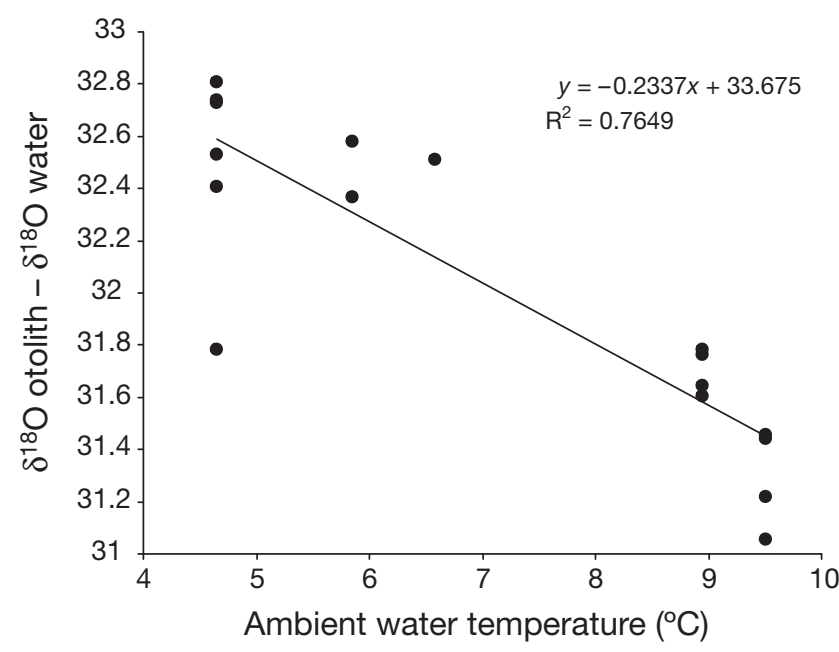

Fig. 3. Coryphaenoides rupestris. Best fit relationship between measured isotope values and ambient water temperature relating to Eq. (2)

where $S$ is salinity (\%). The best fit relationship between measured isotope values and ambient water $\left(\delta^{18} \mathrm{O}_{\mathrm{w}}\right)$, reported relative to the Standard Mean Ocean Water (SMOW) isotope standard, is shown in Fig. 3; and the corresponding equation relating $\delta^{18} \mathrm{O}_{\text {oto }}$ and temperature $T\left({ }^{\circ} \mathrm{C}\right)$ is (error is $\mathrm{SE}$ )

$$
T=\frac{\delta^{18} \mathrm{O}_{\text {oto(PDB })}-\delta^{18} \mathrm{O}_{\mathrm{w}(\mathrm{SMOW})}-3.7769 \pm 0.236}{-0.235 \pm 0.03}
$$

Measured depth profiles of temperature and salinity for the sample locations were obtained for the year and month of capture of fish from each sample site from oceanographic data collected under the project DEECON (www.imr.no/deecon). Values of $\delta^{18} \mathrm{O}_{\mathrm{w} \text { (SMOw) }}$ were then estimated from known salinities according to Eq. (1), and profiles of predicted $\delta^{18} \mathrm{O}_{\text {oto }}$ as a function of depth were produced (Fig. 4). The $95 \%$ precision limits of temperature derived from Eq. (2) are estimated, approximately, to be $\pm 5^{\circ} \mathrm{C}$ for single otolith analyses, and $\pm 2^{\circ} \mathrm{C}$ if 5 otoliths are used to constrain a temperature (Høie et al. 2004a,b). While absolute temperature reconstructions are subject to relatively large prediction errors, the precision of estimates of differences in temperature are largely constrained by measurement error.

Statistical analysis. Average elemental concentration was calculated as element-to-Ca ratios for all life stages for each otolith. Possible correlations among elements and between sex and elemental concentration were tested using a Pearson rank correlation test. No relationship between sex and elemental concentration was found. Elements found to be correlated with each other were included in further multivariate analy- 


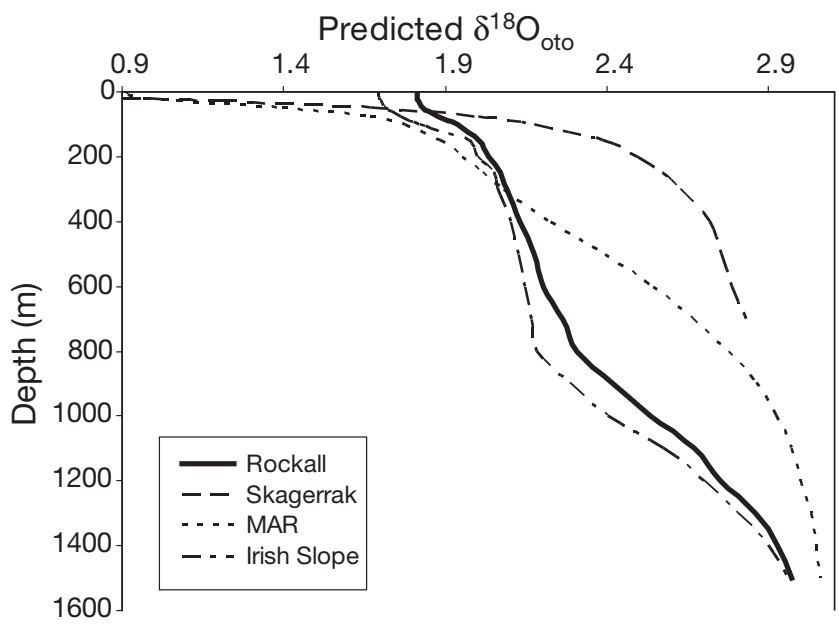

Fig. 4. Coryphaenoides rupestris. Predicted otolith $\delta^{18} \mathrm{O}$ values $\left(\delta^{18} \mathrm{O}_{\text {oto }}\right)$ as a function of depth calculated from CTD profiles of temperature and salinity for 4 sample locations in the northeast Atlantic. MAR: Mid-Atlantic Ridge

ses but were subject to strict tolerance limits. Tolerance measures the correlation of a candidate variable with the variables included in the model, and values range from 0 to 1 . If a variable is highly correlated with one or more of the others, the value of tolerance is small and the resulting estimates of the coefficients may be unstable.

A 1-way repeated measures analysis of variance (ANOVA) (Chambers \& Miller 1995) was carried out to test whether the mean elemental and isotope ratios differed among sampling locations and between life stages. The concentration of conservative elements such as strontium and magnesium in seawater is related to salinity, and effectively constant in open ocean water, but their concentrations in otoliths may vary under physiological control (Kalish 1991b, Campana 1999, Martin et al. 2004, Elsdon et al. 2008, Brown \& Severin 2009). Additionally, in our study, otolith $\mathrm{Mg} / \mathrm{Ca}$ and $\mathrm{Sr} / \mathrm{Ca}$ values were not found to significantly vary among sites $(p<0.05)$. For these reasons, these 2 elements were removed from further analysis.

A repeated measures approach was used to account for non-independence of transect data sampled within each otolith for both microchemical and isotope data. Residuals of these analyses were tested for normality and homogeneity of variance using KolmogorovSmirnov and Levene's tests respectively (Zuur et al. 2007, 2009). These values did not conform to the required assumptions of normality and homogeneity of variance. Therefore, data were $\log _{10}$ transformed after which values conformed to assumptions of normality but not to homogeneity of variance. As a result, an adjusted, more conservative alpha level of 0.005 was used to determine significance for all tests (Underwood 1997). Furthermore a Greenhouse-Geisser correction was included which adjusts the degrees of freedom within the repeated measures ANOVA test in order to obtain a more accurate significance (p) value. A Bonferroni test was used to compare multiple pairwise comparisons of locations based on elemental ratio. All the above analyses were done using the GLM function in PASW Statistics 18.

A stepwise discriminant function analysis (DFA) of the element-to-Ca values for each life stage was used to determine the ability of the overall elemental signature to correctly assign individuals to the area of origin at each point in their life. Tolerance values from the DFA were examined to ensure that the variables included were not artificially affecting the result due to multi-collinearity. The DFA was jack-knifed to determine the discrimination success between the sample areas using SYSTAT 8 (SYSTAT Software 2002). Scatterplots of the first 2 discriminant variate scores were then drawn to visualize this separation.

\section{RESULTS}

\section{Spatial and temporal patterns in otolith microchemistry}

A summary of untransformed elemental concentrations is provided in Table 3. Differences in mean elemental ratios among locations and between life stages were highly significant for all elements (Table 4).

For the primordial region of the otolith (representing the fish early larval phase), all ratios varied among locations (Fig. 5). Li/Ca concentrations were highest in Rockall, and decreased gradually across sites from north to south. Both $\mathrm{Mn} / \mathrm{Ca}$ and $\mathrm{Ba} / \mathrm{Ca}$ ratios showed large differences among locations. Mn/Ca values were very similar between samples from Rockall (highest) and Skagerrak, both having high concentrations when compared to samples from the Irish Slope and MAR. $\mathrm{Mn} / \mathrm{Ca}$ values in samples from the MAR were significantly lower than those from the other 3 sites, and this was a discriminatory feature of this location (Fig. 5). The Ba/Ca concentration in the early larval stage of the fish was highest in fish from the Irish Slope, the deepest of the 4 sample sites (Fig. 5). Samples from Rockall and MAR had similar concentrations of $\mathrm{Ba} / \mathrm{Ca}$ (both caught at $\sim 950 \mathrm{~m}$ depth), while the lowest concentration of $\mathrm{Ba} / \mathrm{Ca}$ was found in samples from the Skagerrak, the shallowest of the 4 sample sites (Table 2).

In the core region of the otolith (late larval), elemental ratios $\mathrm{Li} / \mathrm{Ca}, \mathrm{Mn} / \mathrm{Ca}, \mathrm{Ba} / \mathrm{Ca}$ and $\mathrm{Cu} / \mathrm{Ca}$ showed high variability among sample locations (Table 3, Fig. 5). Li/Ca values were found to be higher in sam- 
Table 3. Coryphaenoides rupestris. Mean (SD) untransformed concentrations of trace elements shown as element-to-Ca ratios per sample location and life stage. MAR: Mid-Atlantic Ridge

\begin{tabular}{|lccccc|}
\hline Site & Li/Ca & Mn/Ca & $\mathrm{Zn} / \mathrm{Ca}$ & $\mathrm{Ba} / \mathrm{Ca}$ & $\mathrm{Cu} / \mathrm{Ca}$ \\
\hline Early larval & & & & & \\
Rockall & $15.22(16.79)$ & $8.33(5.33)$ & $3.72(1.72)$ & $8.86(12.57)$ & $2.45(1.37)$ \\
Skagerrak & $5.92(4.47)$ & $8.19(5.81)$ & $3.03(3.35)$ & $1.81(1.27)$ & $0.95(0.63)$ \\
MAR & $2.55(1.69)$ & $0.82(0.32)$ & $8.51(6.12)$ & $8.63(10.46)$ & $1.76(2.14)$ \\
Irish Slope & $3.42(2.11)$ & $1.76(0.37)$ & $3.99(2.41)$ & $16.03(11.70)$ & $2.88(2.05)$ \\
Late larval & & & & & \\
Rockall & $14.43(16.01)$ & $8.80(5.90)$ & $3.78(1.67)$ & $4.78(4.89)$ & $2.0(1.15)$ \\
Skagerrak & $6.14(4.19)$ & $9.42(4.53)$ & $3.12(2.39)$ & $1.52(0.74)$ & $1.04(0.48)$ \\
MAR & $1.73(1.01)$ & $0.73(0.31)$ & $3.80(2.09)$ & $5.54(6.14)$ & $0.79(0.69)$ \\
Irish Slope & $1.84(0.61)$ & $1.42(0.33)$ & $2.75(2.0)$ & $8.69(5.86)$ & $1.43(1.09)$ \\
Transition & & & & & \\
Rockall & $15.75(15.71)$ & $8.73(6.42)$ & $1.66(1.09)$ & $6.38(3.81)$ & $0.79(0.6)$ \\
Skagerrak & $7.33(4.40)$ & $9.24(4.51)$ & $1.94(1.88)$ & $1.46(0.57)$ & $0.81(0.59)$ \\
MAR & $2.65(1.31)$ & $0.39(0.07)$ & $1.96(1.02)$ & $4.63(3.64)$ & $0.35(0.42)$ \\
Irish Slope & $3.46(1.84)$ & $0.93(0.13)$ & $1.21(1.23)$ & $7.59(3.57)$ & $0.67(0.92)$ \\
Adult & & & & & \\
Rockall & $11.46(11.74)$ & $8.41(5.97)$ & $0.81(0.44)$ & $4.17(1.61)$ & $0.59(0.27)$ \\
Skagerrak & $6.80(3.56)$ & $8.51(4.71)$ & $0.69(0.46)$ & $1.01(0.24)$ & $0.44(0.15)$ \\
MAR & $2.04(0.75)$ & $0.31(0.06)$ & $1.89(1.11)$ & $15.09(7.59)$ & $0.59(0.56)$ \\
Irish Slope & $2.34(1.70)$ & $1.07(0.71)$ & $1.01(1.51)$ & $11.46(6.68)$ & $0.50(0.34)$ \\
& & & & & \\
\hline
\end{tabular}

ples from Rockall and Skagerrak than in the other 2 sample sites, confirming the pattern identified in the early larval phase. $\mathrm{Mn} / \mathrm{Ca}$ ratios were similar in samples from Rockall and Skagerrak (highest) but considerably lower in samples from the Irish Slope and MAR (Table 3); the latter showing the lowest concentrations, which again sets this location apart from the other 3 (Fig. 5). Ba/Ca ratios in the late larval phase mirrored the pattern found in the early larval phase, being highest in samples from the Irish Slope and lowest in samples from the Skagerrak site (Fig. 5). Values of samples from Rockall and MAR were similar.

Entering into the transitional phase (early juvenile), $\mathrm{Li} / \mathrm{Ca}$ values were considerably higher in samples from Rockall and Skagerrak than from the Irish Slope and MAR (Table 3). Mn/Ca ratios were again found to be higher in samples from Skagerrak and Rockall compared with those from the Irish Slope and MAR (Fig. 5). However, Mn/Ca levels decreased in fish from all sample locations from the late larval to the early juvenile phase (Table 3). The pattern of $\mathrm{Ba} / \mathrm{Ca}$ ratios in the early juvenile stage reflected that seen in the early larval and late larval phase chemistry but was more pronounced (Fig. 5).

In the adult phase, the ratios $\mathrm{Li} / \mathrm{Ca}, \mathrm{Mn} / \mathrm{Ca}$, $\mathrm{Ba} / \mathrm{Ca}$ and $\mathrm{Zn} / \mathrm{Ca}$ were found to be highly variable among locations (Fig. 5). Li/Ca values were similar in samples from Rockall and Skagerrak but differed strongly from the more southern sites of the Irish Slope and MAR, which were also of similar concentration to each other (Table 3). $\mathrm{Mn} / \mathrm{Ca}$ values differed little between samples from Rockall and Skagerrak but these locations had markedly higher values than samples from the Irish Slope or MAR (lowest) (Table 3). In the adult phase, $\mathrm{Ba} / \mathrm{Ca}$ concentrations were similar for samples from the Irish Slope and MAR but were markedly lower in Rockall and the Skagerrak samples. A summary of variation in all element-to-Ca ratios among sample locations and life stages and their interaction can be found in Table 4 .

Bonferroni tests allowed multiple comparisons among location based on pooled element-to-Ca ratios from all life stages. Li/Ca was similar in the Irish Slope and MAR, but significantly different $(p<0.005)$ at the other 2 sites, Rockall and Skagerrak, which were also similar to each other. The $\mathrm{Mn} / \mathrm{Ca}$ ratio was significantly different in all cases except between Rockall and the Skagerrak (Fig. 5). Skagerrak had a $\mathrm{Ba} / \mathrm{Ca}$ ratio that was significantly different to all other locations ( $p<0.005)$, Rockall and the Irish Slope were significantly different from each other and both were similar to the MAR. Further details of comparisons of elemental signature among locations are shown in Fig. 5.

Based on overall patterns of spatial variation in elemental concentration among locations, the ratios $\mathrm{Li} / \mathrm{Ca}, \mathrm{Mn} / \mathrm{Ca}, \mathrm{Ba} / \mathrm{Ca}, \mathrm{Zn} / \mathrm{Ca}$ and $\mathrm{Cu} / \mathrm{Ca}$ were chosen for preliminary inclusion in the DFA. The stepwise method of inclusion found that $\mathrm{Zn} / \mathrm{Ca}$ did not contribute to classification success and so this ratio was left out of further analyses. Both $\mathrm{Li} / \mathrm{Ca}$ and $\mathrm{Cu} / \mathrm{Ca}$ contributed equally to discrimination success. However, the tolerance value for $\mathrm{Cu} / \mathrm{Ca}$ was lower than that for

Table 4. Coryphaenoides rupestris. Repeated measures ANOVA (Greenhouse-Geisser) results of elemental profiles across otoliths collected at 4 locations in the northeast Atlantic. Values are shown for $F$, degrees of freedom (in brackets) and $\mathrm{p}$

\begin{tabular}{|lrrr|}
\hline & \multicolumn{1}{c}{ Location } & \multicolumn{1}{c|}{ Life stage } & Location ${ }^{*}$ Life stage \\
\hline $\mathrm{Li} / \mathrm{Ca}$ & $21.36(3)<0.001$ & $7.05(2.42)<0.001$ & $1.76(7.28)<0.009$ \\
$\mathrm{Mn} / \mathrm{Ca}$ & $77.30(3)<0.001$ & $24.49(1.65)<0.001$ & $8.13(4.95)<0.001$ \\
$\mathrm{Cu} / \mathrm{Ca}$ & $9.4(3)<0.001$ & $66.64(2.42)<0.001$ & $4.89(7.28)<0.001$ \\
$\mathrm{Zn} / \mathrm{Ca}$ & $5.51(3)<0.005$ & $129.1(2.36)<0.001$ & $3.44(7.08)<0.005$ \\
$\mathrm{Ba} / \mathrm{Ca}$ & $37.45(3)<0.001$ & $6.22(2.46)<0.001$ & $6.42(7.38)<0.001$ \\
& & & \\
\hline
\end{tabular}



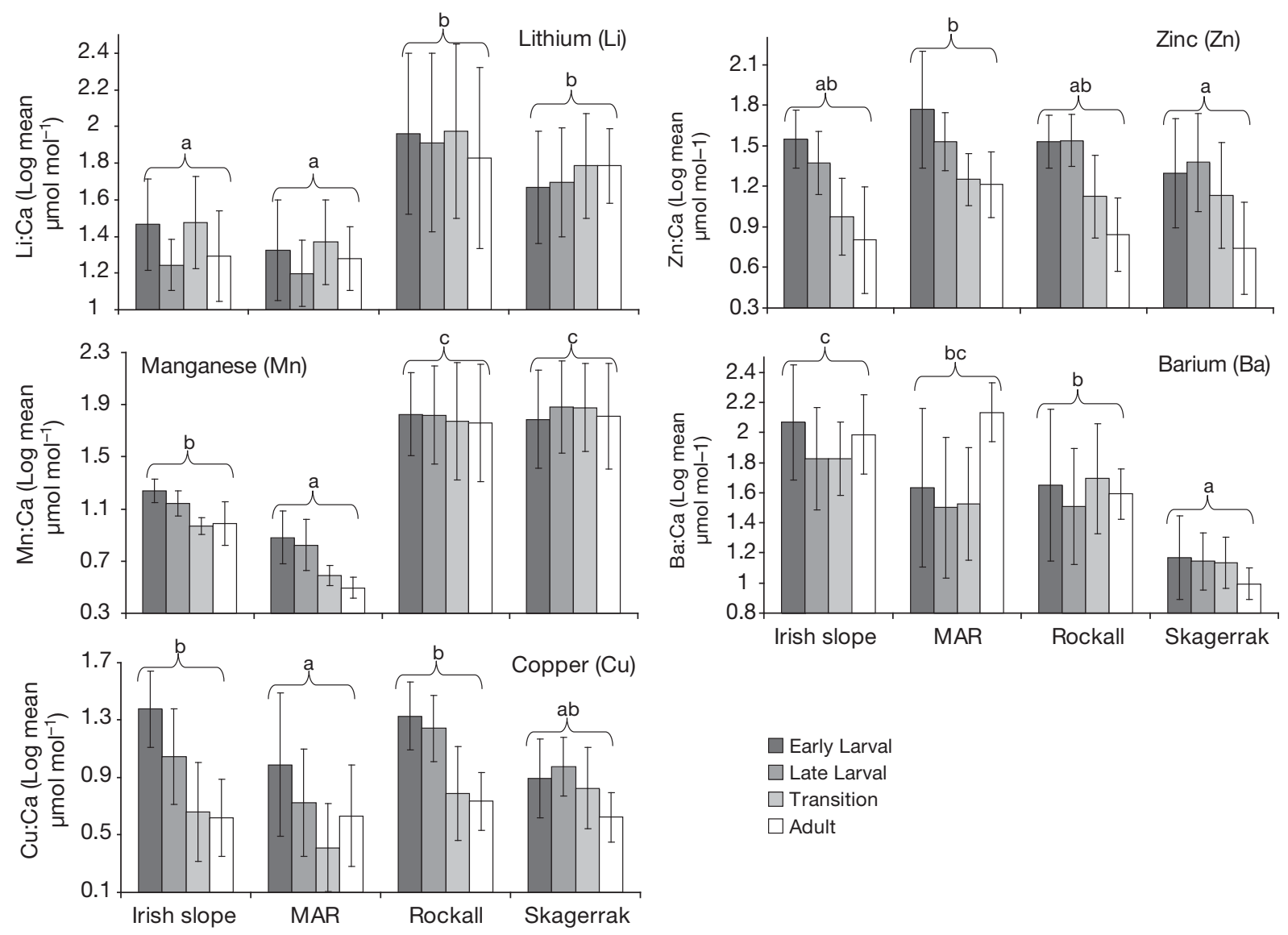

Fig. 5. Coryphaenoides rupestris. Mean elemental ratios ( $\mu \mathrm{mol} \mathrm{mol} \mathrm{m}^{-1} \log _{10}$ transformed) and standard deviations for roundnose grenadier otoliths from each of 4 sample sites and life stages. Any locations not sharing a common letter are significantly different from each other at $\mathrm{p}<0.005$ (Bonferroni test). MAR: Mid-Atlantic Ridge

$\mathrm{Li} / \mathrm{Ca}$ and so $\mathrm{Cu} / \mathrm{Ca}$ was also excluded from the DFA. Both $\mathrm{Mn} / \mathrm{Ca}$ and $\mathrm{Ba} / \mathrm{Ca}$ were found to contribute strongly to the classification. Therefore, the ratios $\mathrm{Li} / \mathrm{Ca}, \mathrm{Mn} / \mathrm{Ca}$ and $\mathrm{Ba} / \mathrm{Ca}$ were chosen for inclusion in the final DFA. Tolerance values for all the 3 variables included were found to be close to 1 , ensuring confidence in the stability and reliability of the procedure. The DFA of early larval stage otolith chemistry gave an overall jack-knifed classification success of $71 \%$ (Fig. 6). For core (late larval) otolith data, the overall jack-knifed classification success was $74 \%$ (Fig. 6), with $\mathrm{Mn} / \mathrm{Ca}$ and $\mathrm{Ba} / \mathrm{Ca}$ contributing most to the classification. For the transitional phase, classification success was $81 \%$, with both $\mathrm{Mn} / \mathrm{Ca}$ and $\mathrm{Ba} / \mathrm{Ca}$ again contributing most to classification. The highest classification was found at the late adult stage, with an overall jack-knifed classification success of $90 \%$ and a $100 \%$ classification success for fish from Skagerrak and MAR. Details on DFA results, per life stage and location, can be found in Table 5 .

\section{Isotope analysis}

Collectively, stable isotope analysis results revealed a consistent pattern of increasing $\delta^{18} \mathrm{O}$ and $\delta^{13} \mathrm{C}$ values with age (Table 6 ). The oxygen isotope ratio became more enriched from the larval to the adult phase in fish from all locations (Table 6), indicating an average equivalent temperature of $6( \pm 1)^{\circ} \mathrm{C}$ in the larval phase, $4( \pm 1)^{\circ} \mathrm{C}$ in mid-life and $3( \pm 1)^{\circ} \mathrm{C}$ in the adult stage. Among locations, there was no significant difference in $\delta^{18} \mathrm{O}$ values with the adjusted alpha of 0.005 (repeated measures ANOVA, $F=6.45, \mathrm{df}=3, \mathrm{p}=0.006$ ), though the probability level is very close to the threshold. Between life stages differences were definitely significant (repeated measures ANOVA, $F=25.56, \mathrm{df}=1.64, \mathrm{p}<$ 0.001). Similarly, $\delta^{13} \mathrm{C}$ values increased significantly from the larval to the adult phase (repeated measures ANOVA, $F=91.46, \mathrm{df}=2, \mathrm{p}<0.001$ ), while $\delta^{13} \mathrm{C}$ values did not differ significantly among locations (repeated measures ANOVA, $F=1.33, \mathrm{df}=3, \mathrm{p}=0.3$ ). 

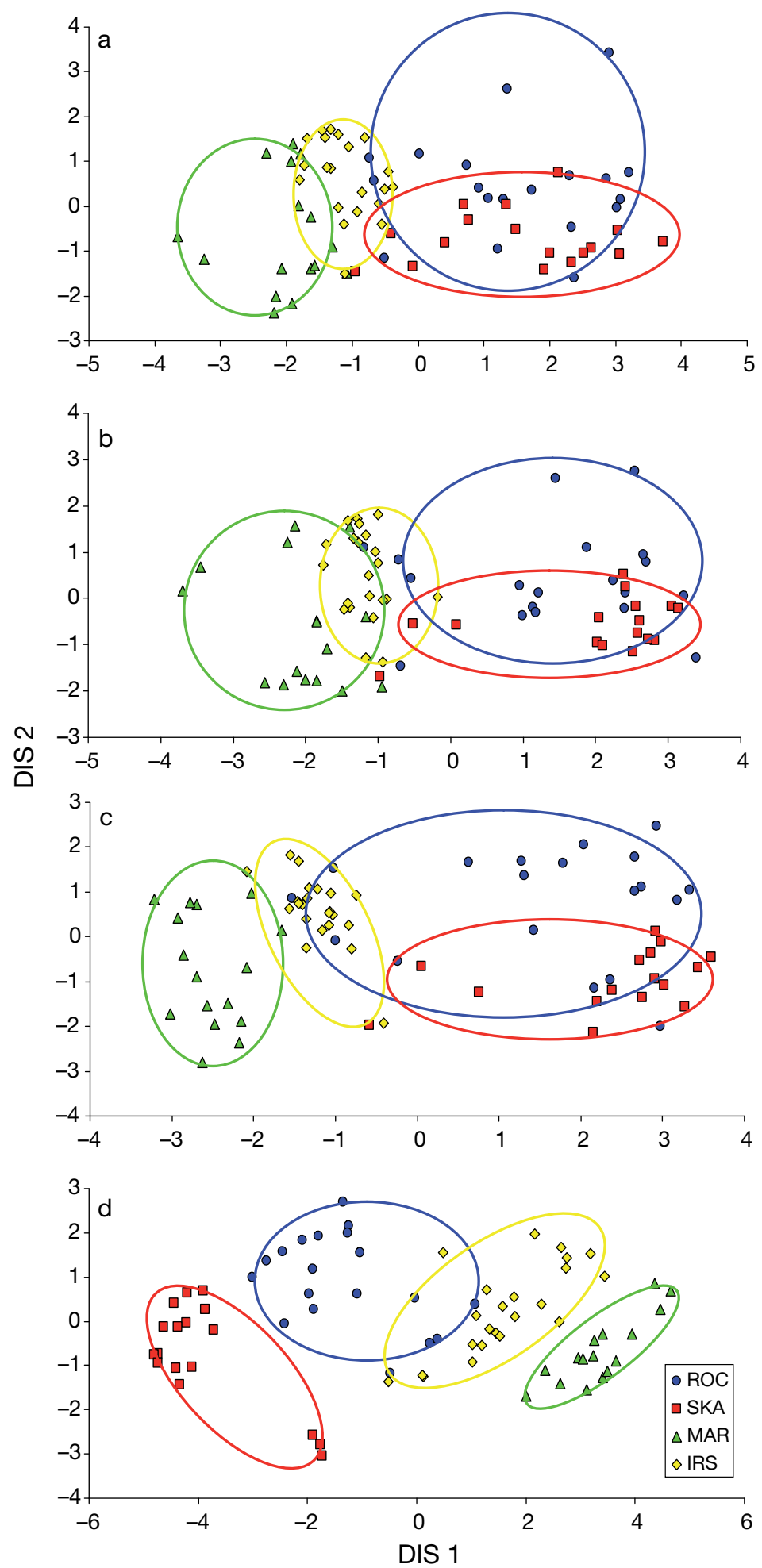

Fig. 6. Coryphaenoides rupestris. Ordination plots of roundnose grenadier individuals of (a) early larval stage, (b) late larval stage, (c) transitional stage and (d) adult stage, using the first 2 canonical variates extracted via stepwise discriminant function (DIS) analysis of elemental ratios. Colour coding identifies sampling locations (ROC: Rockall; SKA: Skaggerak; MAR: Mid-Atlantic Ridge; IRS: Irish Shelf). Ellipses are for visualization purposes only

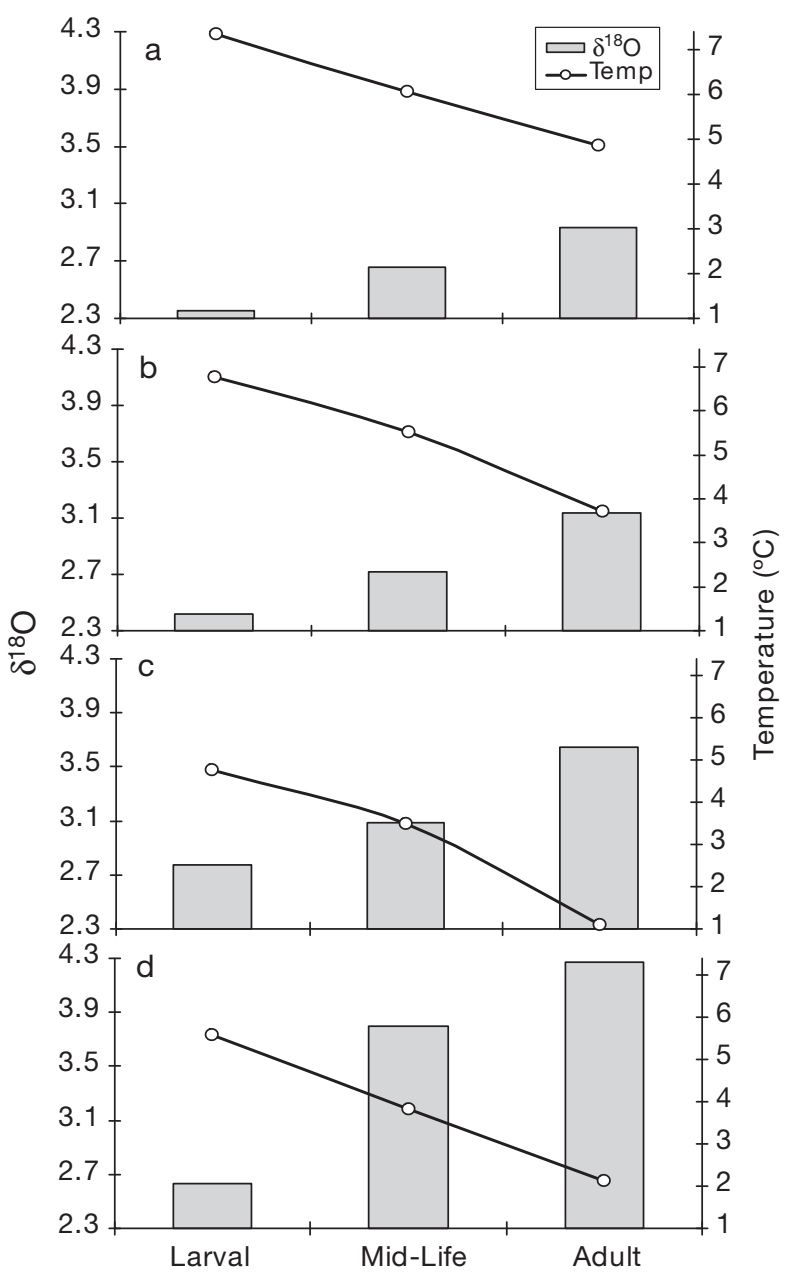

Fig. 7. Coryphaenoides rupestris. Mean oxygen isotope composition (bars) at (a) Rockall, (b) Skagerrak, (c) Mid-Atlantic Ridge and (d) Irish Slope per life stage with equivalent water temperature (lines)

Rockall fish show enrichment in $\delta^{18} \mathrm{O}$ values from the larval phase to mid-life and adult phases (Fig. 7b). This corresponds to surrounding waters of $7( \pm 1), 6( \pm 1)$ and $5( \pm 1)^{\circ} \mathrm{C}$ for early life stage, mid-life and adult phases respectively. The $\delta^{18} \mathrm{O}$ values in the Skagerrak region were similar to those of Rockall, while MAR and Irish Slope isotope ratios were generally higher than those found in Rockall and Skagerrak, thus corresponding to temperatures likely to be approximately $2^{\circ} \mathrm{C}$ lower at each life stage (Fig. 7). $\delta^{13} \mathrm{C}$ values increased consistently from early stages, through mid-life, to the adult phase in all locations (Table 6).

\section{DISCUSSION}

Trace element differences were strong among locations and increased with age, but were also significant 
Table 5. Coryphaenoides rupestris. Jack-knifed classification matrices for discriminant function analysis (DFA) of early larval (EL), late larval (LL), transition phase (T) and late adult (A) elemental ratios among 4 locations in the NE Atlantic. Overall summary and relative proportions are reported in the final 8 columns. MAR: Mid-Atlantic Ridge

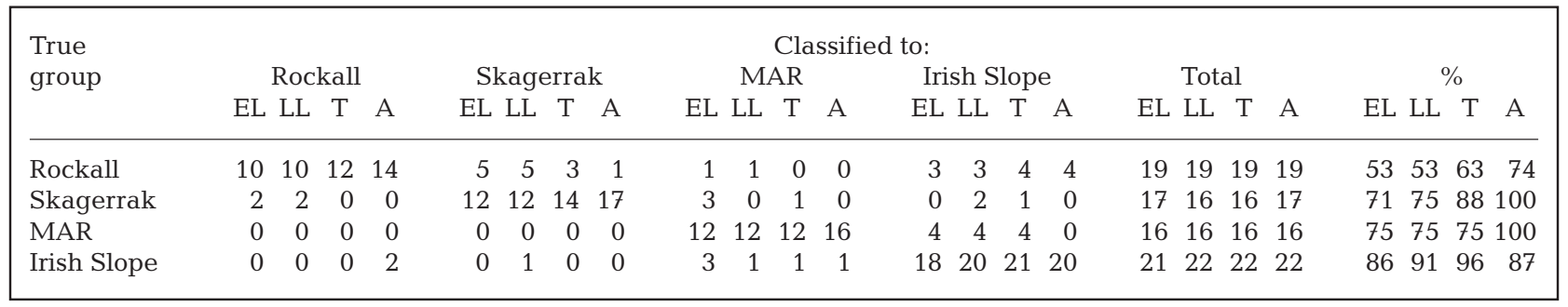

Table 6. Coryphaenoides rupestris. Mean oxygen and carbon stable isotope values (\%) of otoliths per location. MAR: Mid-Atlantic Ridge

\begin{tabular}{|c|c|c|c|c|c|c|c|c|c|}
\hline \multirow[t]{2}{*}{ Location } & \multicolumn{3}{|c|}{ Capture conditions } & \multicolumn{2}{|c|}{ Juvenile } & \multicolumn{2}{|c|}{ Mid-life } & \multicolumn{2}{|c|}{ Adult } \\
\hline & Temp. $\left({ }^{\circ} \mathrm{C}\right)$ & Salinity (\%o) & Season & $\delta^{18} \mathrm{O}$ & $\delta^{13} \mathrm{C}$ & $\delta^{18} \mathrm{O}$ & $\delta^{13} \mathrm{C}$ & $\delta^{18} \mathrm{O}$ & $\delta^{13} \mathrm{C}$ \\
\hline Rockall & 7.44 & 35.21 & Autumn & 2.35 & -3.48 & 2.65 & -3.26 & 2.93 & -2.27 \\
\hline Skagerrak & 6.19 & 35.33 & Autumn & 2.42 & -3.64 & 2.71 & -3.06 & 3.14 & -1.81 \\
\hline MAR & 4.48 & 34.96 & Summer & 2.78 & -4.08 & 3.08 & -3.43 & 3.64 & -1.46 \\
\hline Irish Slope & 5.77 & 35.05 & Autumn & 2.64 & -3.38 & 3.80 & -2.79 & 4.28 & -1.25 \\
\hline Overall mean & 5.97 & 35.13 & - & 2.55 & -3.64 & 3.10 & -3.14 & 3.50 & -1.70 \\
\hline
\end{tabular}

between life stages. Spatial differences were detected at what is assumed to be the early larval stage (71\% classification accuracy), and became more pronounced by the late adult stage ( $90 \%$ ). As such, the populations identified must not only be discrete, but have remained separate throughout the life cycle. Isotopic analysis revealed a consistent pattern of decreasing temperature with age, suggesting ontogenetic vertical depth migration in all locations. The isotopic signal also suggested that metabolic activity decreased gradually with age, which is consistent with the relationship between body size and metabolic rate and migration to deeper waters.

Classification success to location in the late larval phase was similar to that of the early larval phase. Inability to identify the primordium could contribute to the relative lack of location differentiation in the early larval stage. However, classification success increases gradually through all life stages in all populations (not just between the early larval and other life stages), indicating that this is a real effect. Classification success increased by $9 \%$ at the transitional phase (early juvenile), at which stage the fish may become a more active pelagic swimmer (Mauchline et al. 1994). Chemical differences between life stages show that the elements that differed most among locations varied less between life stages. All element-to-Ca ratios showed differences between life stages (Table 3). However, the ratios $\mathrm{Li} / \mathrm{Ca}, \mathrm{Mn} / \mathrm{Ca}$ and $\mathrm{Ba} / \mathrm{Ca}$ showed less inter-life stage variation compared to $\mathrm{Zn} / \mathrm{Ca}$ and $\mathrm{Cu} / \mathrm{Ca}$ ratios.
Concentrations of $\mathrm{Zn}$ and $\mathrm{Cu}$ (Fig. 4) consistently decreased with age in all locations and, while these elements proved ineffective in distinguishing fish from different locations, they might reflect some interesting physiological process.

The lower classification success at the larval stage may be the result of either a more similar water environment experienced by the larvae or indeed effective larval mixing. This uncertainty is an inherent drawback of microchemical techniques. Thus, the increased classification accuracy from larval to adult may have a number of mutually non-exclusive explanations. Firstly, although very little information exists on the occurrence and distribution of eggs and larvae of the roundnose grenadier, from the sparse data available (Lorance et al. 2008, Merrett 1978) eggs appear to hatch at depths significantly shallower than the adult habitat (150-600 m), whereby larvae may be exposed to stronger surface currents and more variably mixed waters, which in turn could lead to a less defined chemical signal. Oxygen isotope data strongly confirm both this shallower larval distribution and the ontogenetic 'depth shift' during the life cycle. Such a progressive depth shift likely takes place over a relatively short time compared to the life span of this species; this could explain the greater variance in elemental concentrations in earlier life stages-particularly evident in Ba (Table 3), an element known to vary greatly with depth (Swan et al. 2003a) — and the reduced statistical power of classification. From a behavioural point of 
view, whilst larvae are subjected to transport via currents, older grenadiers will start swimming actively to their preferred habitats, where they can become resident (Bergstad 1990), hence allowing the build-up of stronger spatial signals. However, the effective longterm impact of what could be some degree of larval exchange among putative stocks can only be assessed by examining molecular genetic markers across these populations, a task that is currently being undertaken (H. Knutsen pers. comm.).

Interestingly, the relative differences among areas varied depending on the ontogenetic stage. Initially, at the early larval stage, Rockall and Skagerrak have relatively similar elemental signatures, but in the adult phase, Rockall individuals appear more similar to the Irish Slope ones. This may reflect the different oceanographic conditions and processes to which larvae (shallower and more susceptible to oceanographic currents) and adults (deeper and necto-benthic) are exposed (Ellett \& Martin 1973, Gordon \& Duncan 1985, Werner et al. 1997).

Overall, the patterns of chemical distinctiveness identified in the present study fit well with the geographical separation of the studied locations. The trace element composition in otoliths of fish from the Skagerrak and MAR segregate to opposite sides of the ordinations in the adult phase (Fig. 6), reflecting their strong chemical differences. Conversely, otoliths from Rockall and Irish Slope fish appear to overlap to some extent, in line with their geographical proximity and most likely reflecting some degree of environmental similarity between the 2 locations (out of 8 fish misclassified in any of these 2 locations, 6 are reciprocally assigned to one another in the adult stage).

The Skagerrak is the shallowest and most enclosed area; waters at this location are strongly influenced by the continental land masses, unlike the waters around Rockall, Irish Slope and the MAR (Danielssen et al. 1996). In earlier studies on deep-sea species, Ashford et al. $(2005,2007)$ reported differentiation in the otolith chemistry of Patagonian toothfish caught between 900 and $1700 \mathrm{~m}$ in the Southern Ocean, and linked these to ocean fronts and variability of water masses (Ashford \& Jones 2007). Similarly, roundnose grenadier in the Skagerrak region are likely to encounter dense shelf water in the Skagerrak trough, with an elemental signature distinct from the rest of the North Atlantic. On the other hand, the similarities between Rockall and the Irish Slope at the adult stage could be explained by the influence of the North Atlantic deep water (NADW) current on both these areas (Rossby 1996, Bacon 1997). The MAR fish are found at a more southerly position, and marked distinctions between this and the other 3 sample locations at the transitional and adult stages may reflect the influence of a different salinity and temperature regime compared to the more northerly locations; the MAR may also be influenced by the spread of Mediterranean and Labrador Sea waters (Paillet et al. 1998).

Previous studies investigating deep dwelling fish in the North Atlantic have found low classification rates of less than $55 \%$ through otolith microchemistry (Swan et al. 2003a,b, Stransky et al. 2005). However, it has been suggested that Coryphaenoides rupestris may not be a long-distance swimmer (Bergstad 1990, Bergstad \& Gordon 1994), which would result in strong spatial segregation at the adult stage.

The present study is one of the first to illuminate the vertical, as well as horizontal nature of roundnose grenadier movement patterns. Based on oxygen isotope profiles for each location, larval grenadiers inhabit a relatively warm habitat, after which a sustained decline in temperature was detected up to and including adulthood. Temperature decreases with depth in the study areas, particularly between 700 and $\sim 1600 \mathrm{~m}$, resulting in a predicted decrease in $\delta^{18} \mathrm{O}_{\text {oto }}$ values with depth (Fig. 4). Measured $\delta^{18} \mathrm{O}_{\text {oto }}$ values can be compared with predicted $\delta^{18} \mathrm{O}_{\text {oto }}$ depth profiles (Fig. 4) to estimate the depth inhabited by the fish during deposition of otolith aragonite. The oxygen isotope composition of otoliths from Rockall implies depth ranges from $\sim 700$ (juvenile) to $>1300 \mathrm{~m}$ (adult), while in the Skagerrak the inferred layers are comprised between 200 (juvenile) and $600 \mathrm{~m}$ (adult); both these results are consistent with the known depth range of Coryphaenoides rupestris (Cohem et al. 1990). Otoliths of fish from the MAR and Irish Slope record the same isotopic pattern of increasing depth with age, but the absolute $\delta^{18} \mathrm{O}_{\text {oto }}$ values are approximately 1 to $1.5 \%$ greater than expected throughout the ontogenetic range. As discussed above, $\delta^{18} \mathrm{O}_{\text {oto }}$ values reflect temperature and the isotopic composition of the ambient water. These 2 localities are the most southerly localities studied, and it is possible that fish in this area could be exposed to Mediterranean outflow water (MOW). MOW is a high salinity deep-water mass, which exits the Mediterranean Sea and spreads into the Atlantic at a depth of $\sim 1000 \mathrm{~m}$. MOW has a $\delta^{18} \mathrm{O}_{\mathrm{w}}$ value in excess of $1.2 \%$, which is significantly higher than that of NADW (Pierre 1999). We know of no direct measurements of $\delta^{18} \mathrm{O}_{\mathrm{w}}$ values at depth in these regions, but the presence of MOW at depth in the Irish Slope and MAR regions could explain the anomalously high $\delta^{18} \mathrm{O}_{\text {oto }}$ values recovered. As discussed above, otoliths from the most southerly MAR region have a distinctive trace element composition, which also supports the possible presence of MOW. The water mass inhabited by fish from the Irish Slope appears to have an isotopic composition suggesting an influence of MOW, but a trace element composition similar to that seen in Rockall, 
whereas the isotopic composition of the most northerly Rockall fish suggests no influence of MOW.

Despite the differences in absolute $\delta^{18} \mathrm{O}_{\mathrm{w}}$ values between regions, the relative changes from warmer (shallower) juvenile habitats to colder (deeper) habitats are consistent across all locations and support the early suggestions of a life-history depth migration of roundnose grenadier in the Skagerrak (Pechenik \& Troyanovskii 1971), also giving it a more universal value.

Otolith carbon is a mixture of both ambient dissolved inorganic carbon (DIC) and metabolically derived carbon (MDC). Both DIC and MDC have distinct isotopic signatures and their proportions incorporated into the otolith are a function of the daily metabolism of the fish (Kalish 1991a, Thorrold et al. 1997, Schwarcz et al. 1998, Weidman \& Millner 2000, Solomon et al. 2006). Therefore, $\delta^{13} \mathrm{C}$ values, which have been shown to reflect levels of metabolically derived carbon in blood plasma (Sherwood \& Rose 2003), vary in accordance with metabolic activity level. Carbon isotope compositions also became more enriched with age, indicating a gradual decline in metabolic rate from the early life to the adult stage, which is also consistent with migration to deeper, colder waters. This pattern was present across all locations with little difference in metabolic rate of fish across sample locations. This might indicate a similar feeding strategy in each location.

Considering laser ablation ICP-MS was implemented as the method of analysis (as opposed to solution-based ICP-MS), sample numbers were deemed adequate to successfully interpret the ontogenetic elemental signature through whole otolith transects. In general, however, the interpretation of the patterns of variability of elemental signatures in otoliths remains problematic (Gillanders \& Kingsford 2000), especially in terms of understanding the relative contributions of extrinsic (aquatic environmental) and intrinsic (physiological and metabolic) processes in determining the actual concentrations recovered in the otolith minerals. High $\mathrm{Mn} / \mathrm{Ca}$ has been related to anthropogenic impacts on riverine inputs (Gillanders \& Kingsford 2000, Turekian \& Tausch 1964). Ba is known to be correlated with biological activity on the overlying surface waters (Swan et al. 2006) and also to increase in concentration with depth and distance from shore (Swan et al. 2003a). High Li levels are thought to relate to input from hydrothermal activity (Bruland 1983) and to co-vary with salinity (Milton et al. 1997, Campana et al. 2000, Milton \& Chenery 2001, Gillanders 2002, Rooker et al. 2003). In the present study, Mn was found in highest concentrations in the Skagerrak and lowest on the MAR. The Skagerrak is a relatively enclosed area of shallower water with a high riverine input. Consequently, a high $\mathrm{Mn} / \mathrm{Ca}$ level should be expected here as a result of continental runoff. In contrast, Ba was found in lowest concentration in the Skagerrak and highest on the MAR and Irish Slope. Since the Skagerrak location is the shallowest and the closest to the continental mass of the 4 locations, fish inhabiting it are expected to exhibit relatively low $\mathrm{Ba} / \mathrm{Ca}$. The high variance observed in $\mathrm{Ba} / \mathrm{Ca}$ between life stages (Table 3) may account for the somewhat lower classification success at this life stage compared to the others.

In agreement with previous results (Bergstad 1990), our study identified a distinct stock in the Skagerrak (Devine \& Haedrich 2008) and likely independent stocks in other regions, especially the MAR. These stocks appear to operate as separate units. As such, it is hoped that the management process will start to recognize the existence of stock discontinuities in this currently overexploited deep-sea species. Additionally, efforts should be made to improve our perception of stocks that possess an important vertical dimension to their structuring and/or life history (Cadrin et al. 2010). In conclusion, the otoliths of roundnose grenadier populations from different areas across the northeast Atlantic exhibited clearly divergent signatures of trace element chemistry throughout their life history, indicating that they remain permanently geographically discrete. Furthermore, all populations displayed analogous, yet not identical, ontogenetic depth migrations. The present study therefore indicates that roundnose grenadier populations are highly structured across the northeast Atlantic Ocean. Further insights into the historical stability of these geographical patterns and their consequences for the recent evolution of these populations could be garnered by analyzing chemical and genetic data from the same individuals in a common statistical framework.

Acknowledgements. This work is part of C.L.'s PhD studies, financially supported by the European Science Foundation (EuroDEEP), the Irish Research Council for Science, Engineering and Technology, and the MARECO network. We are indebted to all scientific and commercial fishing expeditions that provided samples, including cruises by Scottish, Irish, Portuguese and Norwegian crews. Finally, we express our gratitude to all members of the DEECON project (www.imr.no/deecon) for the many insightful discussions on population structure in the deep sea, and to 2 anonymous reviewers for their constructive criticism.

\section{LITERATURE CITED}

Allain V (2000) Age estimation and growth of some deep-sea fish from the Northeast Atlantic ocean. Cybium 24:7-16

Ashford JR, Jones C (2007) Oxygen and carbon stable isotopes in otoliths record spatial isolation of Patagonian toothfish (Dissostichus eleginoides). Geochim Cosmochim Acta 71:87-94

> Ashford JR, Jones CM, Hofmann E, Everson I, Moreno C, Duhamel G, Williams R (2005) Can otolith elemental sig- 
natures record the capture site of Patagonian toothfish (Dissostichus eleginoides), a fully marine fish in the Southern Ocean? Can J Fish Aquat Sci 62:2832-2840

Ashford JR, Arkhipkin AI, Jones CM (2006) Can the chemistry of otolith nuclei determine population structure of Patagonian toothfish Dissostichus eleginoides. J Fish Biol 69:708-721

Ashford JR, Arkhipkin AI, Jones CM (2007) Otolith chemistry reflects frontal systems in the Antarctic Circumpolar Current. Mar Ecol Prog Ser 351:249-260

Ashford JR, Jones CM, Hofmann EE, Everson I, Moreno CA, Duhamel G, Williams R (2008) Otolith chemistry indicates population structuring by the Antarctic Circumpolar Current. Can J Fish Aquat Sci 65:135-146

Atkinson DB (1981) Partial length as a replacement for total length in measuring grenadiers. J Northwest Atl Fish Sci 2:53-56

Atkinson DB (1995) The biology and fishery of roundnose grenadier (Coryphaenoides rupestris Gunnerus, 1765) in the north-west Atlantic. In: Hopper AG (ed) Deep-water fisheries of the North Atlantic oceanic slope. Kluwer Academic Publishers, Dordrecht, p 51-112

Bacon S (1997) Circulation and fluxes in the north Atlantic between Greenland and Ireland. J Oceanogr 27:1420-1435

> Bergstad OA (1990) Distribution, population structure, growth and reproduction of the roundnose grenadier Coryphaenoides rupestris (Pisces: Macrouridae) in the deep waters of the Skagerrak. Mar Biol 107:25-39

Bergstad OA, Gordon JDM (1994) Deep-water ichthyoplankton of the Skagerrak with special reference to Coryphaenoides rupestris Gunnerus, 1765 (Pisces, Pacrouridae) and Argentina silus (Ascanius, 1775) (Pisces, Argentinidae). Sarsia 79:33-43

- Bergstad OA, Gjelsvik G, Schander C, Høines ÅS (2010) Feeding ecology of Coryphaenoides rupestris from the Mid-Atlantic Ridge. PLoS ONE 5:e10453

Bridger JP (1978) New deep-water trawling grounds to the west of Britain. Laboratory leaflet 41, Ministry of Agriculture, Fisheries and Food, Lowestoft

Brown RJ, Severin KP (2009) Otolith chemistry analyses indicate that water $\mathrm{Sr}: \mathrm{Ca}$ is the primary factor influencing otolith Sr:Ca for freshwater and diadromous fish but not for marine fish. Can J Fish Aquat Sci 66:1790-1808

Bruland KW (1983) Trace elements in seawater. Chem Oceanogr 8:157-220

Cadrin S, Friedland K, Waldman J (2005) Stock identification methods: applications in fishery science. Elsevier Academic Press, San Diego, CA

Cadrin SX, Bernreuther M, Danielsdottir AK, Hjorleifsson E and others (2010) Population structure of beaked redfish, Sebastes mentella: evidence of divergence associated with different habitats. ICES J Mar Sci 67:1617-1630

Campana SE (1999) Chemistry and composition of fish otoliths: pathways, mechanisms and applications. Mar Ecol Prog Ser 188:263-297

- Campana SE (2005) Otolith science entering the 21st century. Mar Freshw Res 56:485-495

Campana SE, Chouinard GA, Hanson JM, Frechet A, Brattey $\mathrm{J}$ (2000) Otolith elemental fingerprints as biological tracers of fish stocks. Fish Res 46:343-357

Carvalho GR, Hauser L (1994) Molecular genetics and the stock concept in fisheries. Rev Fish Biol Fish 4:326-350

Chambers RC, Miller TJ (1995) Evaluating fish growth by means of otolith increment analysis: special properties of individual-level longitudinal data. In: Secor DH, Dean JM, Campana SE (eds) Recent developments in fish otolith research. University of South Carolina Press, Columbia,
SC, p 155-175

Cohen DM, Inada T, Iwamoto T, Scialabba N (1990) FAO species catalogue, Vol 10. Gadiform fishes of the world (Order Gadiformes). An annotated and illustrated catalogue of cods, hakes, grenadiers and other gadiform fishes known to date. FAO Fish Synop No. 125, Vol 10, FAO, Rome

Craig H, Gordon LI (1965) Deuterium and oxygen-18 variations in the ocean and marine atmosphere. In: Tongiogi $\mathrm{E}$ (ed) Proc Stable Isotopes Oceanogr Stud Paleotemp, Spoleto, Italy. Consiglio Nazionale delle Ricerche, Pisa, p 9-130

Danielssen DS, Svendsen E, Ostrowski M (1996) Long-term hydrographic variation in the Skagerrak based on the section Torungen-Hirtshals. ICES J Mar Sci 53:917-925

Devine J, Haedrich R (2008) Populations trends and status of two exploited Northwest Atlantic grenadiers, Coryphaenoides rupestris and Macrourus berglax. Am Fish Soc Symp 63:463-484

Duschenko V, Savvatimskiy P (1988) Intraspecific structure of the rock grenadier, Coryphaenoides rupestris, of the northern Atlantic: variability of local groups and reasons for their formation. J Ichthyol 28:22-30

Ehrich S (1983) On the occurrence of some fish species at the slopes of the Rockall Trough. Arch Fisch Wiss 33:105-150

Ellett DJ, Martin JHA (1973) The physical and chemical oceanography of the Rockall channel. Deep-Sea Res Oceanogr Abstr 20:585-625

> Elsdon TS, Gillanders BM (2003) Reconstructing migratory patterns of fish based on environmental influences on otolith chemistry. Rev Fish Biol Fish 13:217-235

Elsdon TS, Gillanders BM (2004) Fish otolith chemistry influenced by exposure to multiple environmental variables. J Exp Mar Biol Ecol 313:269-284

Elsdon TS, Wells BK, Campana SE, Gillanders BM and others (2008) Otolith chemistry to describe movements and lifehistory parameters of fishes: hypotheses, assumptions, limitations and inferences. Oceanogr Mar Biol Annu Rev 46:297-330

> Gillanders BM (2002) Temporal and spatial variability in elemental composition of otoliths: implications for determining stock identity and connectivity of populations. Can J Fish Aquat Sci 59:669-679

> Gillanders BM, Kingsford MJ (2000) Elemental fingerprints of otoliths of fish may distinguish estuarine 'nursery' habitats. Mar Ecol Prog Ser 201:273-286

Gordon JDM, Duncan JAR (1985) The ecology of the deepsea benthic and benthopelagic fish on the slopes of the Rockall Trough, Northeastern Atlantic. Prog Oceanogr 15: $37-69$

> Gordon JDM, Swan SC (1996) Validation of age readings from otoliths of juvenile roundnose grenadier, Coryphaenoides rupestris, a deep-water macrourid fish. J Fish Biol 49:289-297

Hauser L, Carvalho GR (2008) Paradigm shifts in marine fisheries genetics: ugly hypotheses slain by beautiful facts. Fish Fish 9:333-362

Hauser L, Seeb JE (2008) Advances in molecular technology and their impact on fisheries genetics. Fish Fish 9:473-486

- Hilborn R, Walters CJ (1992) Quantitative fisheries stock assessment: choice, dynamics and uncertainty. Rev Fish Biol Fish 2:177-178

> Høie H, Andersson C, Folkvord A, Karlsen Ø (2004a) Precision and accuracy of stable isotope signals in otoliths of pen-reared cod (Gadus morhua) when sampled with a high-resolution micromill. Mar Biol 144:1039-1049

> Høie H, Otterlei E, Folkvord A (2004b) Temperature-dependent fractionation of stable oxygen isotopes in otoliths of 
juvenile cod (Gadus morhua L.). ICES J Mar Sci 61:243251

Ihssen PE, Booke HE, Casselman JM, McGlade JM, Payne NR, Utter FM (1981) Stock identification: materials and methods. Can J Fish Aquat Sci 38:1838-1855

Kalish JM (1991a) ${ }^{13} \mathrm{C}$ and ${ }^{18} \mathrm{O}$ isotopic disequilibria in fish otoliths: metabolic and kinetic effects. Mar Ecol Prog Ser 75:191-203

Kalish JM (1991b) Determinants of otolith chemistry: seasonal variation in the composition of blood-plasma, endolymph and otoliths of bearded rock cod Pseudophycis barbatus. Mar Ecol Prog Ser 74:137-159

Kelly CJ, Connolly PL, Bracken JJ (1996) Maturity, oocyte dynamics and fecundity of the roundnose grenadier from the Rockall Trough. J Fish Biol 49 (Supp A):5-17

Kelly CJ, Connolly PL, Bracken JJ (1997) Age estimation, growth, maturity and distribution of the roundnose grenadier from the Rockall Trough. J Fish Biol 50:1-17

Kingsford MJ, Hughes JM, Patterson HM (2009) Otolith chemistry of the non-dispersing reef fish Acanthochromis polyacanthus: cross-shelf patterns from the central Great Barrier Reef. Mar Ecol Prog Ser 377:279-288

Logvinenko BM, Nefedov GN, Massal'skaya LM, Polyanskaya IB (1983) A population analysis of rock grenadier based on the genetic polymorphism of non-specific esterases and myogenes. Can Trans Fish Aquat Sci 5406

Longmore C, Fogarty K, Neat FC, Brophy D, Trueman CN, Milton JA, Mariani S (2010) A comparison of otolith microchemistry and otolith shape analysis for the study of spatial variation in a deep-sea teleost, Coryphaenoides rupestris. Environ Biol Fishes 89:591-605

Lorance P, Garren F, Vigneau J (2001) Age estimation of roundnose grenadier (Coryphaenoides rupestris), effects of uncertainties on ages. J Northwest Atl Fish Sci 31: 387-399

Lorance P, Large PA, Bergstad OA, Gordon JDM (2008) Grenadiers of the Northeast Atlantic-distribution, biology, fisheries, and their impacts, and developments in stock assessment and management. Am Fish Soc Symp 63: 365-397

Lowe WH, Allendorf FW (2010) What can genetics tell us about population connectivity? Mol Ecol 19:3038-3051

Martin GB, Thorrold SR, Jones CM (2004) Temperature and salinity effects on strontium incorporation in otoliths of larval spot (Leiostomus xanthurus). Can J Fish Aquat Sci 61: $34-42$

Mauchline J, Bergstad OA, Gordon JDM, Brattegard T (1994) The food of juvenile Coryphaenoides Rupestris Gunnerus, 1765 (Pisces, Macrouridae) in the Skagerrak. Sarsia 79: 163-164

Merrett NR (1978) On the identity and pelagic occurrence of larval and juvenile stages of rattail fishes (Family Macrouridae) from $60^{\circ} \mathrm{N}, 20^{\circ} \mathrm{W}$ and $53^{\circ} \mathrm{N}, 20^{\circ} \mathrm{W}$. DeepSea Res 25:147-160

> Milton DA, Chenery SR (1998) The effect of otolith storage methods on the concentrations of elements detected by laser-ablation ICPMS. J Fish Biol 53:785-794

Milton DA, Chenery SR (2001) Can otolith chemistry detect the population structure of the shad hilsa Tenualosa ilisha? Comparison with the results of genetic and morphological studies. Mar Ecol Prog Ser 222:239-251

Milton DA, Chenery SR, Farmer MJ, Blaber SJM (1997) Identifying the spawning estuaries of the tropical shad, terubok Tenualosa toli, using otolith microchemistry. Mar Ecol Prog Ser 153:283-291

Paillet J, Arhan M, McCartney MS (1998) Spreading of Labrador Sea water in the eastern North Atlantic. J Geo- phys Res 103:10223-10239

Patterson WP, Smith GR, Lohmann KC (1993) Continental paleothermometry and seasonality using the isotopic composition of aragonitic otoliths of freshwater fishes. In: Swart P, Lohmann KC, McKenzie J, Savin S (eds) Continental climate change from isotopic records. Am Geophys Union Monogr 78:191-202

Pechenik LN, Troyanovskii FM (1971) Trawling resources on the North-Atlantic continental slope. Israel Program for Scientific Translations, Jerusalem

> Pierre C (1999) The oxygen and carbon isotope distribution in the Mediterranean water masses. Mar Geol 153:41-55

Proctor CH, Thresher RE (1998) Effects of specimen handling and otolith preparation on concentration of elements in fish otoliths. Mar Biol 131:681-694

Rice AL, Billett DSM, Thurston MH, Lampitt RS (1991) The Institute of Oceanographic Sciences biology programme in the Porcupine Seabight: background and general introduction. J Mar Biol Assoc UK 71:281-310

> Rooker JR, Secor DH, Zdanowicz VS, Itoh T (2001) Discrimination of northern bluefin tuna from nursery areas in the Pacific Ocean using otolith chemistry. Mar Ecol Prog Ser 218:275-282

Rooker JR, Secor DH, Zdanowicz VS, De Metrio G, Relini LO (2003) Identification of Atlantic bluefin tuna (Thunnus thynnus) stocks from putative nurseries using otolith chemistry. Fish Oceanogr 12:75-84

Rooker JR, Secor DH, DeMetrio G, Kaufman AJ, Belmonte Ríos A, Tičina V (2008) Evidence of trans-Atlantic movement and natal homing of bluefin tuna from stable isotopes in otoliths. Mar Ecol Prog Ser 368:231-239

Rossby T (1996) The North Atlantic current and surrounding waters: at the crossroads. Rev Geophys 34:463-481

Schwarcz HP, Gao Y, Campana S, Browne D, Knyf M, Brand $\mathrm{U}$ (1998) Stable carbon isotope variations in otoliths of Atlantic cod (Gadus morhua). Can J Fish Aquat Sci 55: 1798-1806

Shephard S, Trueman C, Rickaby R, Rogan E (2007) Juvenile life history of NE Atlantic orange roughy from otolith stable isotopes. Deep-Sea Res I 54:1221-1230

Sherwood GD, Rose GA (2003) Influence of swimming form on otolith $\delta^{13} \mathrm{C}$ in marine fish. Mar Ecol Prog Ser 258: 283-289

Shiao JC, Yui TF, Høie H, Ninnemann U, Chang SK (2009) Otolith $\mathrm{O}$ and $\mathrm{C}$ stable isotope compositions of southern bluefin tuna Thunnus maccoyii (Pisces: Scombridae) as possible environmental and physiological indicators. Zool Stud 48:71-82

Solomon CT, Weber PK, Ingram BL, Conrad ME and others (2006) Experimental determination of the sources of otolith carbon and associated isotopic fractionation. Can J Fish Aquat Sci 63:79-89

Stransky C (2003) Shape analysis and microchemistry of redfish otoliths: investigation of geographical differences in the North Atlantic. NAFO Scientific Council Research Document, 03/17

> Stransky C, Garbe-Schönberg C, Günther D (2005) Geographic variation and juvenile migration in Atlantic redfish inferred from otolith microchemistry. Mar Freshw Res 56:677-691

Swan SC, Gordon JDM, Morales-Nin B, Shimmield T, Sawyer T, Geffen AJ (2003a) Otolith microchemistry of Nezumia aequalis (Pisces: Macrouridae) from widely different habitats in the Atlantic and Mediterranean. Mar Biol Assoc UK 83:883-886

Swan SC, Gordon JDM, Shimmield T (2003b) Preliminary investigations on the uses of otolith microchemistry for 
stock discrimination of the deep-water black scabbardfish (Aphanopus carbo) in the North East Atlantic. J Northwest Atl Fish Sci 31:221-231

Swan SC, Geffen AJ, Gordon JDM, Morales-Nin B, Shimmield T (2006) Effects of handling and storage methods on the concentrations of elements in deep-water fish otoliths. J Fish Biol 68:891-904

SYSTAT (Software 2002) SYSTAT for Windows, Version 8. SYSTAT Software, Richmond, CA

Thorrold SR, Campana SE, Jones CM, Swart PK (1997) Factors determining ${ }^{13} \mathrm{C}$ and ${ }^{18} \mathrm{O}$ fractionation in aragonitic otoliths of marine fish. Geochim Cosmochim Acta 61: 2909-2919

Turekian KK, Tausch EH (1964) Barium in deep-sea sediments of the Atlantic Ocean. Nature 201:696-697

Underwood AJ (1997) Experiments in ecology. Their logical design and interpretation using analysis of variance. Cambridge University Press, Cambridge

Wang CH, Lin YT, Shiao JC, You CF, Tzeng WN (2009) Spatio-temporal variation in the elemental compositions of

Editorial responsibility: Stylianos Somarakis,

Heraklion, Greece otoliths of southern bluefin tuna Thunnus maccoyii in the Indian Ocean and its ecological implication. J Fish Biol 75: 1173-1193

Waples RS, Punt AE, Cope JM (2008) Integrating genetic data into management of marine resources: How can we do it better? Fish Fish 9:423-449

Weidman CR, Millner R (2000) High-resolution stable isotope records from North Atlantic cod. Fish Res 46:327-342

Werner FE, Quinlan JA, Blanton BO, Luettich RA (1997) The role of hydrodynamics in explaining variability in fish populations. J Sea Res 37:195-212

White TA, Stamford J, Hoelzel RA (2010) Local selection and population structure in a deep-sea fish, the roundnose grenadier (Coryphaenoides rupestris). Mol Ecol 19: $216-226$

Zuur AF, Ieno EN, Smith GM (2007) Analysing ecological data. Springer, New York, NY

Zuur AF, Ieno EN, Walker N, Saveliev AA, Smith GM (2009) Mixed effects models and extensions in ecology with R. Springer, New York, NY

Submitted: October 8, 2010; Accepted: May 4, 2011

Proofs received from author(s): July 28, 2011 